\title{
Sustaining Food Production: Fisheries Management Options for Lake Ardibo, Northern Ethiopia
}

\author{
Wubshet Asnake Metekia ${ }^{1,2}$ \\ ${ }^{1}$ Faculty of Veterinary Medicine, Department of Food Hygiene and Technology, Near East University, Nicosia, Northern Cyprus, TRNC \\ ${ }^{2}$ Ministry of Agriculture of the Federal Democratic Republic of Ethiopian, Addis Ababa, Ethiopian
}

\section{Email address:}

wublivelygib@gmail.com

\section{To cite this article:}

Wubshet Asnake Metekia. Sustaining Food Production: Fisheries Management Options for Lake Ardibo, Northern Ethiopia. Chemical and Biomolecular Engineering. Vol. 4, No. 1, 2019, pp. 14-18. doi: 10.11648/j.cbe.20190401.13

Received: April 4, 2019; Accepted: May 20, 2019; Published: June 10, 2019

\begin{abstract}
Lake Ardibo is one of the important freshwater lakes in northern Ethiopia and today it supports many fishers and their families, who are directly depend on the lake fishery for their protein food source and income generation. The open nature of the fishery resource and high unemployed youth participation in the fishing activity is urgent call and in the long term the lake fishery may become overexploited and collapse so there is a need to introduce some management options for the lake by assessing the current condition using fishermen and key expert interviews as well other secondary data assessment and after this using simple excel sheet and expert analysis were used to compile this paper. Hence based on the analyzed data and observation the fishermen are welling to practice licensing, mesh size regulation, gear restriction and closed season in lake Ardibo fishery. Finally, the researcher recommend that the fishermen should aware about the fish stock resource condition i.e. their market size of the fish, breeding season, area and practices for the sustainable food production from the lake and lastly the regional fishery proclamation should be enforced and applied on the ground.
\end{abstract}

Keywords: Lake Ardibo, Fishery, Fishermen, Sustainable Food Production and Management

\section{Introduction}

Lake Ardibo is found in the north-eastern part of Ethiopia in south Wollo zone of the Amhara region. It is located at 110 $10^{\prime} 26.9^{\prime \prime} \mathrm{N}, 39045^{\prime} 19.2^{\prime \prime} \mathrm{E}$ at an altitude of 2000 masl. The surface area of the lake and its catchment is $21 \mathrm{~km}^{2}$ and 52.6 $\mathrm{km}^{2}$, respectively. The Lake Ardibo catchment is a closed drainage within the northwestern watershed of the Awash River basin, near the head water of Mille River. The area is dominantly hilly and intensively cultivated. This highaltitude area is characterized by scattered bushes and grazing fields. The climate is sub-humid with average annual temperature and rainfall of $180 \mathrm{C}$ and 1158 millimeters, respectively. The Lake has a maximum depth of $65 \mathrm{~m}$. The Lake has almost similar $\mathrm{pH}$ with that of Lake Hayq (8.5). The surface oxygen is about $4.15 \mathrm{mg} / \mathrm{lit}$ and surface temperature is relatively colder than Lake Hayq (16.30C). The lake is more turbid with vertical visibility of $1.4 \mathrm{~m}$. Ankerka River flows out of Lake Ardibo and drain into Lake Hayq. Lake Ardibo and Hayq are situated in two separate craters within a small graben bounded to the east and west by distinct NNW-SSE tending major fault systems. Unlike the typical circular shape of a crater lake, later modification by faulting gave an elongated shape for Lake Ardibo [1-2].

Lake Ardibo is one of the most important bird areas of Ethiopia. A total of 73 bird species were identified in this lake and its surroundings. The fish species found in this lake are not indigenous. The lake harbours two fish species introduced for fisheries and weeds control. Nile tilapia (Orechromis niloticus) and Carp (Cyprinus carpio). Lake Ardibo was stocked more recently with fish from Hayq and has a lower abundance [3].

In general, the lake ecosystem supports both aquatic and terrestrial biodiversity, such as migratory birds, wildlife, fishery resources and vegetations. Lakes Ardibo and Hayq serve as wintering grounds and maintenance stations for a large number of terrestrial and aquatic birds. Lake Ardibo has more infringing papyrus swamps, which support a unique habitat for freshwater biodiversity and source of animal feed during the dry season. The most important component of the water balance of Lake Ardibo is input from rainfall and outflow by evaporation. The ground water inflow appears to 
be higher than the inflow. The bathymetric map shows that much of the surface area of the lake is shallow accommodating many aquatic biotas.

When we see the socio-economic and cultural significance of Lake Ardibo; it is mainly used for irrigation and fishery purpose. Irrigation aqueduct and canal were constructed for irrigation by the government at the northwestern shore of the lake some time in 1989 with a designed capacity of 300 litters per second, which is now irrigating $1.5 \mathrm{~km}^{2}$ of land. The irrigation scheme allows the farmer to produce at least two times a year. The lake is also serving as drinking water source for humans and animals. Fisheries resource contributes a lot in food security in this area. For Lakes Ardibo, there are about 153 registered fisher and other unregistered individual fisher in which their livelihood is dependent on it. There is one fisher cooperative working on production and marketing; and the fish produced from Ardibo is transported to and marketed at Haik, Kombolcha, Dessie, Woldia, Debre Brehan and Addis Ababa [3].

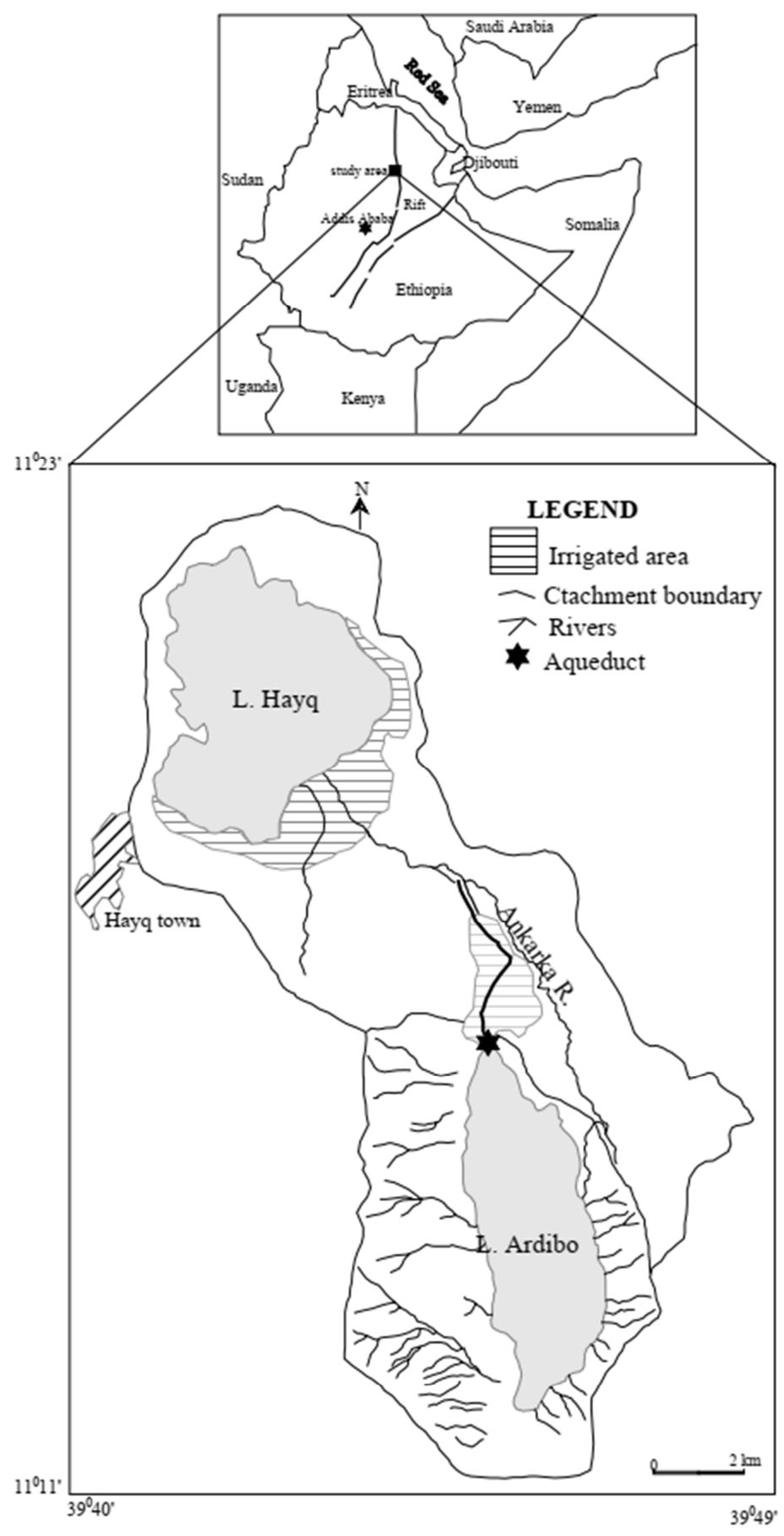

Figure 1. Map of Ethiopia and the two Lakes- lake Hayq and Lake Ardibo [18].

Map of Lake Ardibo (Study Area). 


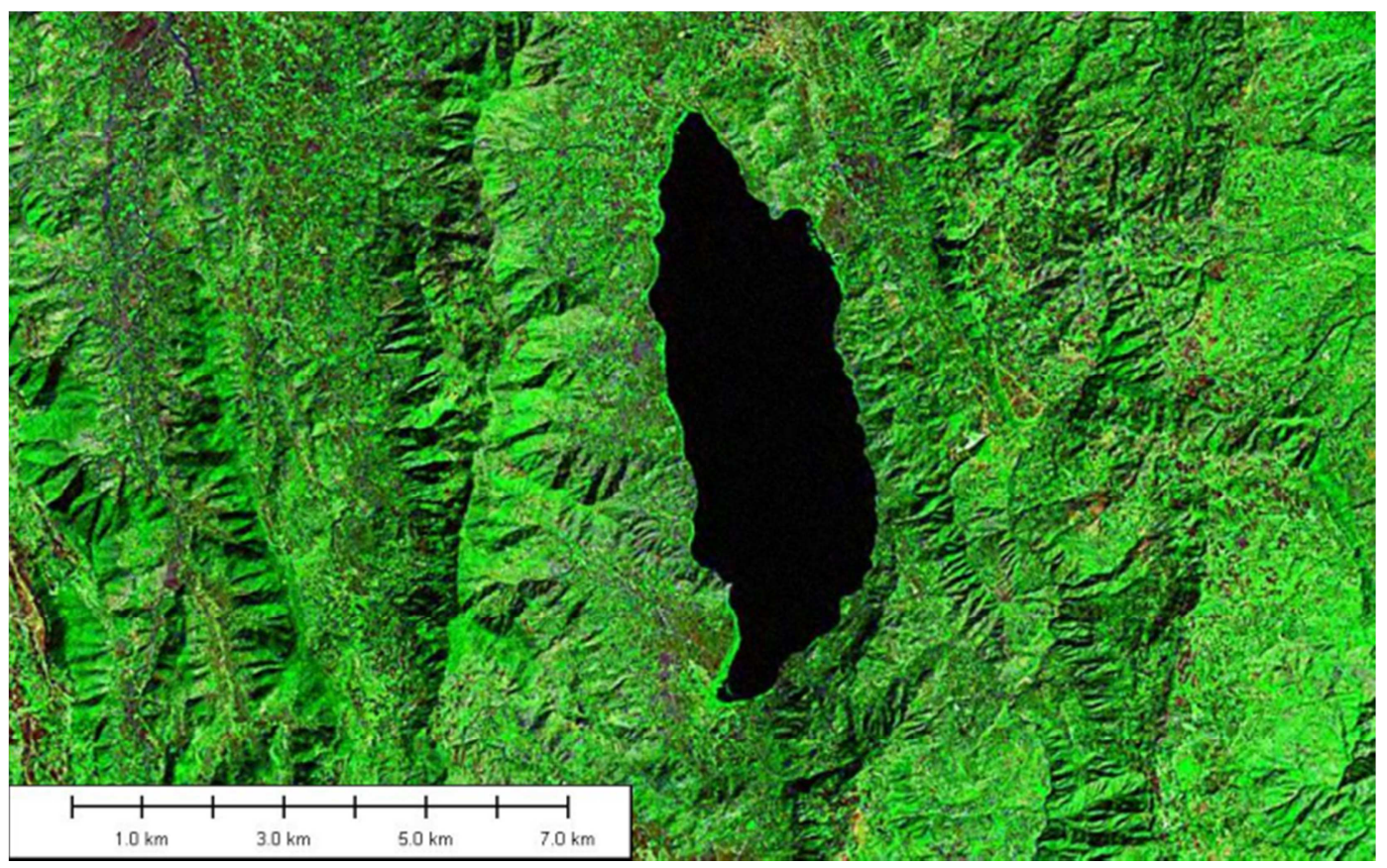

Figure 2. Satellite image of Lake Ardibo [8].

\section{Objective}

To Survey the fishery management practice in Lake Ardibo and introducing and establishing better fishery resource management system for the lake.

\section{Methodology}

In this research we developed questioner on freshwater fisheries management and utilization (both open ended and closed questioner) and made 40 individual fisherman and 10 key expert interviewing including selected group discussion were made. And also, secondary data from different sources were collected (catch reports, federal and regional fishery management laws) after that it was analyzed using simple excel worksheet and expert view analysis.

\section{Result and Discussion}

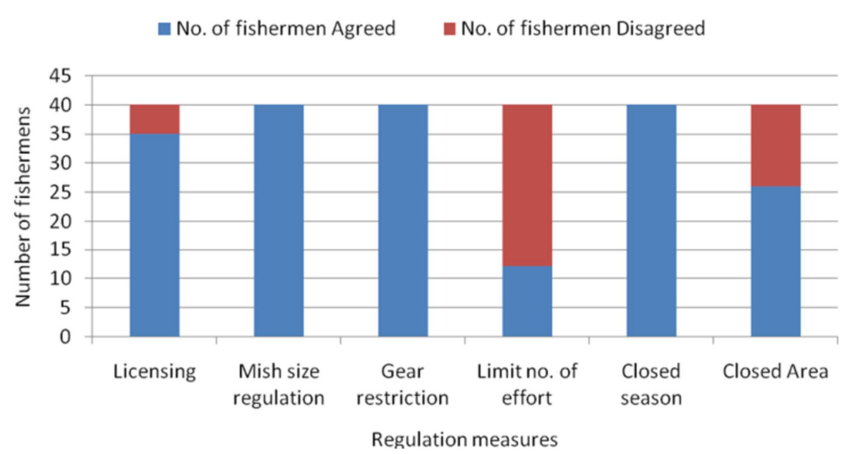

Figure 3. Fishermen respond to regulation measures in Lake Ardibo.

Before the introduction of motorized boats, the fishery was confined to the inshore areas not more than some meters away from landing site. This was due to the lower carrying capacity, lower speed (paddling) and energy consuming nature of wood boats that cannot increase its mobility longer distance. The introduction of motorized boat fishery is increasing the catch year to year these days in respect to increased concentration of fishing entirely through the whole area of the lake. By any means fishing during the spawning season is banned in this area: seasonal closure was given first priority.

The other justification is to avoid overcapitalization for the future. Lake Ardibo is assumed to have a virgin stock. Based on this idea, effort is increasing year to year. In the long-run if it continues like this, there will be a time that average cost is greater than average revenue from the fishery and then less than normal profit will be being earned. If they get a negative profit, they will leave the fishery. Capital for the poor fisherman is limited. So, management is important in this situation to avoid overcapitalization by restricting effort and restricting from entering the fishery from further negative earnings. Efficient fisheries management is essential to maximize and sustain benefits from a fishery [4-6].

\subsection{Identification of the Reference Points for Lake Ardibo}

The implementation of regional regulations is becoming urgent to maximize the stable production and employment levels in the area. To define such, save levels, several criteria may be used as shown in figure 1 above. The criteria need to be revised and checked on a regular basis to reflect the new data as and when they become available.

\subsection{Maximum Sustainable Yield Criterion}

The spread of using new technology of fishing in Lake Ardibo is gradually increasing since the introduction of motorized boats in recent years by ORDA project. Hence Continuous technological change may cause the catch to 
increase up to Maximum Sustainable Yield (MSY) level of that stock, but after MSY the increase in technology will not bring any increase in output instead there will be a decrease in catch leading the collapse of the stock in the long-run. So early warning is important before this situation is going to occur. In this regard, limiting the effort level is very important.

On average the lake produced $98.1 \mathrm{~kg}$ per hectare per year or 206 tons per annum on a sustainable basis. provided an offshore fishery can be developed especially in areas where locally known as 029 and 030 kalu woreda side [7-8].

\subsection{Fish Size Criteria}

Because the current knowledge of the fisheries biology of the Cypernus carpio and Oreochromis niloticus do not make it possible to define targets for each of these species, the following minimum fish sizes are proposed to safeguard the recruitment [8]. The mean size of fish in the landings should not be allowed to drop below:

i. $25.5 \mathrm{~cm}$ for Oreochromis niloticus.

ii. $18 \mathrm{~cm}$ for Cypernus carpio.

Effort is to be allowed to increase until either these minimum fish sizes is reached first. At that stage further expansion of effort would be blocked unless new data would suggest that it is possible. In applying the management tools, the following criteria must be considered. That is the capability of the regulation to ensure the greatest fishing net contribution to the local economy i.e. the capability of the fishery nets in catching the fish particularly in reference to the type of the fish species in the water body and their average stock size. The tools must have sufficient flexibility to allow changes in policy to be implemented quickly. Regulation must have sufficient acceptance from fishermen and other vested interests so that agreement can be reached, institutional and legislative programmers designed and implemented, and enforcement procedures easily and effectively put in to practice. In general, management tools should be in line with policy directives.

\subsection{Regulation Measures That Must Be Taken in Lake Ardibo}

\subsubsection{Licensing of Fishing Units}

A fisherman is any person who fully or partially depends on income from the fishing. A fishing unit is the smallest possible economic unit carrying out fishing activities. There are two basic kinds of fishing units on the lake:

i. A motorized fishing unit typically comprising a motorized boat, a crew of two or more fishermen, and two or more gill nets.

ii. A traditional fishing unit comprising one fisherman and his gears and fishing bamboo boats.

In Lake Ardibo fishing was carried out for commercial purposes and as a subsistence activity; Commercial fishing units fish primarily to sell their catch. Subsistence fishing is mostly for home consumption of the fishermen involved. To be able to control the total fishing effort it is necessary to introduce a licensing system. Any fishing unit fishing for commercial purposes should be licensed. A fishing license must state the following points: number and type of nets (mesh size, length, and height), name of the fishermen and the type of fishing boats [9].

In view of the still under-developed status of the fishery, it is proposed that licensing will be on demand as long as the minimum fish sizes in the landings or a total of the recommended gill net units are not reached. In accordance with the Constitution, the licence is issued against the payment of a fee. However, that fee can be kept at a nominal level for the time being to avoid putting any brakes on the development of the fishery. Later on, it could be used as a way to control total effort [10]. In lake Ardibo if a licensing is practiced (i.e. fishermen written commitment with the government regarding the resource utilization like allowed legal fishing nets, boats, how much can produce per month, allowed fishing days or months, closed seasons or breeding seasons, lake fishery management, watershed management, illegal fishing control, reporting to the concerned office about their fish catch, and other issues will be included here), then the certificate commits the fisherman in two aspects first to respect the fishery regulation and secondly collaborate in the data collection done by fisheries officers. Fishermen not respecting theses commitments could have their licenses revoked. Fishing without a valid license could results in the confiscation of all the gears used.

\subsubsection{Closed Season and Area}

Closed area: The bigger the closed area the more effective it is. However, fishermen communities are likely to want it to be as remote from their actual fishing grounds and landing points as possible. This tool is probably most adequate for lakes where some areas are not yet fished or little fished therefore in this lake Ardibo three areas (zones) are identified, the first is littoral zone sampling site 1 (011 kebele zone side, Tehuledery Woreda), the second one is sampling site 2 (029 kebele zone side, Kalu Woreda side) and the other is 018 kebele zone side, Tehuledery Woreda. Closed areas or "Aquatic Parks" are often recommended to preserve the biodiversity (example: cichlids in the African great lakes).

Closed seasons: Based on the data February, March, April, May, June and October represented the peaks spawning (breeding) period of both C. carpio and O. niloticus in this lake, Lake Ardibo. The local community and the fishermen agree on the peak and reserves four months to be closed; February, March, April and May [7].

\subsubsection{Gear Restrictions}

According to Zikre Hig and key expert interview fishing gears and practices including destructive gears (such as poisoning, inclusive by the traditional Berbera, and explosives), fishing practices which hinder the free movement of spawners and beach seines and trawls are banned and forbidden in the lake Ardibo fishery [9].

\subsubsection{Gear Specifications}

Based on the data for the size at first maturity and the selection factors, it is recommended that the minimum mesh 
size for the lake should be $80 \mathrm{~mm}$ as this would guarantee that most fish caught are mature. A gill net would have a maximum length of $100 \mathrm{~m}$.

\subsubsection{Control}

Fishermen should be encouraged to report any illegal fishing activity they notice. Fishery officers would have the full right to check all fishing gears and fishing on closed area and seasons. Governmental institutions, both at the Woreda and Zone, the courts as well as the police, need to be involved in enforcement [9].

\section{Conclusion and Recommendation}

Generally, Lake Ardibo fisheries resource is limited unless and otherwise we manage well. Hence the fishermen should be aware of their fish stock resource condition i.e. their breeding time/season, breeding place, market size fish, fishing practice, water usage and other activities and practices for sustainable food production, and hence the researcher recommends implementation of co-management system using the guideline of co-management principles and measures including licensing, breeding season and area closure, gear restriction and mesh size regulation should be practiced and in place.

\section{References}

[1] Tenalem Ayenew and Molla Demellie, 2004. Bathymetric survey and estimation of the water balance Of Lake Ardibo, Northern Ethiopia. SINET: Ethiop. J. Sci., 27 (1): 61-68.
[2] BFALRC, 2005. Bahir Dar Fisheries and Other Aquatic Life Research Center Base Line Survey.

[3] South Wollo Zone Livestock and Fisheries Development Office reports and other basic zonal documents, 2009, Dessie Ethiopia.

[4] Eshete Dejen, Jacobus Vijverberg, Leopold A. J. Nagelkerke and Ferdinand A. Sibbing, 2009. Growth, biomass, and production of two small barbs (Barbus humilis and $\mathrm{B}$. tanapelagius, Cyprinidae) and their role in the food web of Lake Tana (Ethiopia). Hydrobiologia.

[5] Fiona McCormack, 2016. Sustainability in New Zealand's quota management system: A convenient story, Anthropology Programme, University of Waikato, New Zealand.

[6] Ladu and Neiland, 1997. Fisheries Management in Lake Chad and Niguru- Gashua Wetlands (N. E Nigeria).

[7] Asnake W, Mingist M (2018) Freshwater Fisheries Resource Potential Estimation: The case of Lake Ardibo, Northern Ethiopia. Fish Aqua J 9: 239. doi: 10. 4172/2150-3508. 1000239 .

[8] Wubshet Asnake, 2010. Fish Resource Potential and some Reproductive aspects of Oreochromis niloticus and Cyprinus carpio in Lake Ardibo, Northern Ethiopia, M. Sc. Thesis Bahir Dar University.

[9] Zikre Hig, 2003. The Amhara National Regional State Fisheries Development, Prevention and its Utilization. Proclamation 92/2003. The Council of the Amhara National Regional State, Bahir Dar, Ethiopia.

[10] Chalachew Aragaw, 2017. Training Manual of Fish Resource and Development, Amhara Region Berao of Agriculture and Rural Development, Bahir Dar (unpublished.). 